Running Head: CHILD/TEACHER EFFORTFUL CONTROL

\title{
Considering Child Effortful Control in the Context of Teacher Effortful Control: \\ Implications for Kindergarten Success
}

\author{
Larissa Michelle Gaias \\ larissa.gaias@asu.edu \\ Tashia Abry \\ tabry@asu.edu \\ Jodi Swanson \\ jodi.swanson@asu.edu \\ Richard A. Fabes \\ rfabes@asu.edu \\ Arizona State University \\ T. Denny School of Social and Family Dynamics \\ 951 S. Cady Mall \\ Tempe, AZ 85281
}

Corresponding Author:

Larissa Gaias

Email: larissa.gaias@asu.edu

Phone: (+001) 631-375-1849

Mailing Address: 909 N. $5^{\text {th }}$ Street, Phoenix, AZ 85004 
Considering Child Effortful Control in the Context of Teacher Effortful Control:

Implications for Kindergarten Success 


\begin{abstract}
Children's effortful control (EC) has been consistently predicts academic and social adjustment; however, researchers have not yet examined children's EC in conjunction with the EC of their teachers. Using membership to EC similarity/dissimilarity pairings, we examined whether the alignment of kindergarten children's EC levels and their teachers' EC levels (e.g., high child EC/high teacher EC, low child EC/high teacher EC) was associated with math and reading performance, school liking, and closeness and conflict in student-teacher relationships. Results from multilevel regression models indicated that high-EC children who had high-EC teachers tended to have better basic math and reading scores and enjoy school more than their peers in other pairings. Low-EC children who had high-EC teachers had the least close and most conflictual relationships with their teachers. Findings have implications for professional development aimed to help teachers better understand and respond to students temperamentally similar or dissimilar to themselves.
\end{abstract}

Keywords: child effortful control; teacher effortful control; kindergarten adjustment; academic performance; student-teacher relationships 
Considering Child Effortful Control in the Context of Teacher's Effortful Control:

Implications for Kindergarten Success

\section{Introduction}

Children's effortful control (EC) is a robust predictor of adaptive functioning across developmental domains in early schooling (Blair \& Razza, 2007; McClelland et al., 2007; Valiente, Lemery-Chalfant, \& Swanson, 2010; Valiente et al., 2011). EC, defined as "the ability to inhibit a dominant response to perform a subdominant response and/or to activate a subdominant response, to plan, and to detect errors" (Rothbart \& Bates, 2006, p. 126), is a set of temperamentally based skills that form the basis of self-regulation. As with children, teachers' self-regulatory ability appears to play a role in children's early school adjustment (Brown, Jones, LaRusso, \& Aber, 2010; Hamre \& Pianta, 2001); however, investigators have yet to examine children's EC in the context of their teachers' EC, and whether child-teacher EC similarities or dissimilarities have implications for children's early school success.

These associations may be particularly salient during kindergarten, when children are transitioning to formal schooling and developing academic competencies, attitudes toward school, and relationships that affect their educational and social trajectories (Duncan et al., 2007; Hamre \& Pianta, 2001). Kindergarten is many children's first exposure to formal schooling (Rimm-Kaufman \& Pianta, 2000), where the groundwork is laid for future cognitive and socioemotional maturity (Ray \& Smith, 2010). Teachers play a particularly influential role during this transition (Love, Logue, Trudeau, \& Thayer, 1992), as evidenced by the multitude of teaching practices and characteristics contributing to early school success (Early, Pianta, \& Cox, 1999; Rimm-Kaufman, Pianta, \& Cox, 2000); however, teachers' temperamental characteristics remain largely understudied. 
This study extends existing research by examining variability in children's academic (math and reading performance; school liking) and relational (teacher-child closeness and conflict) adjustment in kindergarten as a function of similarities or dissimilarities between children's EC and that of their teacher. Knowledge of whether and how children's EC operates on early school adjustment in the context of teachers' EC may inform teacher training and professional development toward building understanding of student-teacher dynamics.

\subsection{Child EC, Teacher EC, and Children's School Adjustment}

\subsubsection{The role of children's EC.}

EC typically encompasses dimensions of inhibitory control and attention-focusing (Posner \& Rothbart, 2000); individuals high in EC can control a negative impulse to a particular stimulus (e.g., grabbing a toy from a peer, giving up on a difficult task) in favor of a more socially acceptable response (e.g., asking to share a toy, persisting with a difficult task; Rudasill, Niehaus, Buhs, \& White, 2013). In the classroom, children high in EC are better able than children low in EC to follow teachers' instructions, process task-related information, sit still, remain focused on classroom activities (Rothbart \& Jones, 1998; Sektnan, McClelland, Acock, \& Morrison, 2010), and refrain from behavioral disruptions (Blair, Dehman, Kochanoff, \& Whipple, 2004; Olson, Sameroff, Kerr, Lopez, \& Wellman, 2005).

The neural network responsible for EC and other higher-order cognitive functions develops rapidly between the ages of 4-7 years and is susceptible to environmental influence, making EC an important characteristic to consider in the context of children's early school adjustment (Carlson, 2005; Kochanska, Murray, \& Harlan, 2000; Rothbart \& Bates, 2006). Indeed, a growing literature has linked children's EC to academic performance and engagement in school, likely because EC enables children to focus on tasks without getting distracted by 
competing stimuli (Duncan et al., 2007; Raver, 2002; Valiente et al., 2011). Poor regulatory skills in kindergarten have predicted difficulty with reading and math through sixth grade, as well as other measures of academic success, including low grades and absenteeism (Duncan et al., 2007; McClelland, Acock, \& Morrison, 2006; NICHD, 2003; Valiente, Lemery-Chalfant, Swanson, \& Reiser, 2008). Furthermore, EC is associated with school liking concurrently and longitudinally across elementary grades (Iyer, Kochenderfer-Ladd, Eisenberg, \& Thompson, 2010; Valiente et al., 2008), likely because children high in EC are better able to participate in and focus on classroom tasks and activities, and regulate their responses to the sometimes stressful demands of the classroom (Valiente et al., 2012). EC is also consistently associated with social functioning (Cumberland-Li, Eisenberg, \& Reiser, 2005), including the formation of positive relationships with adults in the classroom (Rothbart \& Bates, 2006). Children high in EC tend to have closer and less conflictual student-teacher relationships across elementary grades and samples (Rudasill, 2011; Rudasill \& Rimm-Kaufman, 2009; Swanson, Valiente, \& LemeryChalfant, 2012). Despite the importance of children's EC for early school adjustment, little is known about how children's EC operates in the context of the EC of primary socializers, such as teachers. This study represents an important first step toward addressing this gap.

\subsubsection{The role of teachers' $E C$.}

Teachers bring their own unique temperamental characteristics to the classroom, which can affect their interactions with students and the classroom climate (Keogh, 2003). Given the number of competing tasks teachers must balance throughout the school day, teachers' ability to regulate behavioral responses likely helps them successfully supervise their classrooms, manage frustration, and promote student success (Raver, Blair, \& Li-Grining, 2012). Despite the expected influence of teachers' self-regulation on student functioning, there are few 
examinations of teachers' self-regulatory competence and even fewer examining EC specifically.

Moreover, researchers have only recently begun to conceptualize how teachers' self-regulatory abilities relate to their students' outcomes (Raver et al., 2012). In support of theorized links, limited empirical evidence suggests optimally regulated teachers can more effectively manage classroom behavior and respond to children in constructive ways (Sutton \& Wheatley, 2003). Other preliminary research has linked teachers' self-regulation with positive student-teacher interactions, relationships, and overall classroom quality (Brown et al., 2010; Conduct Problems Prevention Research Group, 1999). This emerging line of inquiry highlights the importance of extending empirical examinations of teachers' EC.

\subsection{Considering Child and Teacher EC in the Classroom}

Clear links exist between children's EC and positive adjustment in early schooling, and theoretical and preliminary empirical research exists regarding the influence of teachers' EC on formative classroom processes. Still, extant research has typically focused on children's EC in isolation, or in conjunction with other child characteristics or aspects of the socialization context that do not include the temperament of the socializers themselves (Bates \& Pettit, 2007; Iyer et al., 2010; Valiente et al., 2010; Valiente et al., 2011; Zetner \& Bates, 2008). As a result, data on whether and how child EC supports school adjustment differentially for children with low- or high-EC teachers remains elusive. Guided by a goodness-of-fit theoretical framework (Thomas \& Chess, 1977), we sought to address this gap.

The goodness-of-fit perspective suggests the influence of a particular temperamental trait on a child's functioning depends partly on the features of the environment within which the child is developing, including the sociocultural context, socialization practices, and temperamental characteristics of primary socializers (Wachs, 2000). As such, particular environmental 
conditions may be beneficial or detrimental for an individual child dependent on the child's temperamental profile, regardless of whether those temperament traits are typically viewed as risk or protective factors. For example, in the classroom context, it might be expected that a child would have added difficulty adjusting to school if both the student and teacher were low in EC; however, it could be that a low-EC child would feel comfortable and function well in a class led by a low-EC teacher because this pair connects on a temperamental similarity (e.g., a low-EC teacher might less frequently implement structures and expectations that would be stressful for a low-EC child). In this light, the interplay between children and teachers both low in EC, for example, might benefit relational outcomes, such as closeness and conflict in the student-teacher relationship, compared to academic outcomes.

Alternatively, a low-EC child may benefit from a teacher high in EC, who presumably may be better able than a low-EC teacher to structure, scaffold, and constructively respond to the behavioral tendencies of a low-EC child. This latter hypothesis is consistent with the broad body of evidence indicating that supportive environments may be particularly important for the most at-risk students (Hamre \& Pianta, 2005; Morrison \& Connor, 2002; Rimm-Kaufman et al., 2002). The interplay between a low-EC child and high-EC teacher may be particularly salient to academic outcomes, as teachers high in EC may be better able than their low-EC counterparts to model regulatory competencies and show greater patience with struggling students, ultimately boosting academic skills. Still, it seems unlikely these children would perform at or above the ability of their high EC peers. In sum, the potential for low- and high-EC children to demonstrate similar adjustment dependent on their teachers' EC levels suggests value in comparing outcomes across all possible child-teacher EC pairings.

\subsection{The Present Study}


We examined whether children's membership in child-teacher EC pairing groups (i.e., high-high, high-low, low-high, and low-low) was related to kindergarten adjustment (i.e., basic math and reading, school liking, and closeness and conflict in student-teacher relationships) beyond the influences of other child and classroom characteristics. Considering teachers' influence on children's school adjustment, an investigation of the interplay between children's and teachers' EC may illuminate nuances in relations between children's EC and adaptive early school functioning that may differ across outcomes. Whereas high child EC might be most important for academic outcomes (irrespective of EC-similarity to the teacher), a match between child and teacher EC might be more important for building close student-teacher relationships. We hypothesized high-EC children paired with high-EC teachers would demonstrate stronger basic math and reading skills and would enjoy school more than all other groups, followed by pairings in which either children or teachers were high in EC, and then by low-EC children paired with low-EC teachers. For relational outcomes, we hypothesized that children with similar levels of EC to their teachers (i.e., high-EC children with high-EC teachers or low-EC children with low-EC teachers) would have closer and less conflictual relationships with their teachers than would children in pairings with teachers who differ from them.

\section{Method}

\subsection{Participants and Procedures}

We recruited 174 children and their 11 teachers in full-day regular kindergarten classrooms in a large, metropolitan city in the southwestern United States (Table 1 contains sample characteristics). Data were collected during the month of April in children's kindergarten

year, via teacher questionnaires and 30-minute child direct assessments conducted at school by trained research assistants. The response rate among teachers was $100 \%$ and direct assessments 
were administered to $99 \%$ of participating children. Additionally, school records from the beginning of the school year provided information on child demographics and literacy skills at kindergarten entry.

\subsection{Measures}

\subsubsection{Effortful control.}

Teachers reported on children's EC using the Children's Behavior Questionnaire - Short Form (CBQ-Short; Putnam \& Rothbart, 2006). The EC scale of the CBQ-Short included 12 items assessing four subscales: Inhibitory Control, Attention Focusing, Low Intensity Pleasure, and Perceptual Sensitivity ( $\alpha=.70$; e.g., "When building or putting something together, this child becomes very involved in what s/he is doing, and works for long periods"). Teachers reported on their own EC using the Adult Temperament Questionnaire - Short Form (ATQShort; Evans \& Rothbart, 2007), measured with 18 items assessing Attention Control, Inhibitory Control, and Activation Control ( $\alpha=.82$; e.g., "When interrupted or distracted, I usually can easily shift my attention back to whatever I was doing before"). CBQ and ATQ items were rated on a 7-point Likert scale $(1=$ extremely untrue, $7=$ extremely true $)$. Items within a CBQ or ATQ subscale were averaged and then subscale scores were averaged to create an individual-level EC composite score for each child or teacher, respectively.

\subsubsection{Child-teacher effortful control pairings.}

We assigned children and teachers to a high- or low-EC category based on their individual score relative to the scale midpoint. Unlike the median or mean, the scale midpoint is not affected by sample characteristics. Specifically, any participant who scored between 1.00 and 3.99 was considered $l o w-E C$ ( $M$ for children low in $\mathrm{EC}=3.26 ; M$ for teachers low in $\mathrm{EC}=3.37$ ); participants who scored between 4.00 and 7.00 were considered high-EC ( $M$ for children high in 
$\mathrm{EC}=5.07 ; M$ for teachers high in $\mathrm{EC}=4.83$ ). Next, we created four dummy-coded variables representing membership in the possible child-teacher EC pairs: All children belonged to one of four possible mutually exclusive pairings: (a) Child high in $\mathrm{EC}$, teacher high in $\mathrm{EC}\left(\mathrm{H}_{\mathrm{C}} \mathrm{H}_{\mathrm{T}}\right)$; (b) Child high in EC, teacher low in EC $\left(\mathrm{H}_{\mathrm{C}} \mathrm{L}_{\mathrm{T}}\right)$; (c) Child low in $\mathrm{EC}$, teacher high in $\mathrm{EC}\left(\mathrm{L}_{\mathrm{C}} \mathrm{H}_{\mathrm{T}}\right)$; or (d) Child low in EC, teacher low in EC $\left(\mathrm{L}_{\mathrm{C}} \mathrm{L}_{\mathrm{T}}\right)$. Group membership variables were used as the predictors of interest in all analyses.

2.2.3 Basic math and reading. Trained research assistants directly assessed children on two subtests from the Woodcock-Johnson III Tests of Achievement (WJ-III; Woodcock, McGrew, \& Mather, 2007). Applied Problems assessed mathematical problem-solving, requiring participants to listen to a problem, identify the necessary procedure, and then perform a basic calculation. Letter-Word Identification assessed basic reading through examinees' sightidentification of letters and words. Standardized W scores were computed using WJ-III software to derive age- and grade-based equivalents for each subscale.

2.2.4 School liking. Children reported on how much they liked school using the School Liking and Avoidance Questionnaire (Ladd \& Price, 1987). Children rated seven items (e.g., "Do you like being in school?") on a 3 -point scale $(1=$ never, $3=$ always; $\alpha=.68)$, averaged to create a composite score, with higher scores representing greater school enjoyment.

2.2.5 Student-teacher relationship. Teachers rated how much closeness and conflict they experienced with each participating child in their classroom using two subscales from the Student-Teacher Relationship Scale (Pianta, 2001). Closeness was rated using seven items (e.g., "I share an affectionate, warm relationship with this child"; $\alpha=.93$ ), and conflict was rated using eight items (e.g., "This child and I always seem to be struggling with each other"; $\alpha=.93$ ). All 
items were rated on a 5-point scale $(1=$ Definitely does not apply, $5=$ Definitely applies $)$ and averaged within subscale, with higher scores representing greater closeness or conflict.

2.2.6 Covariates. To better isolate the unique influence of EC-pairing membership on adjustment outcomes, we considered a robust set of covariates. Child covariates included negative affect (12 items, $\alpha=.77$ ) and surgency (12 items, $\alpha=.68$ ), assessed using teachers' reports on the CBQ-Short (Putnam \& Rothbart, 2006), as well as age and sex drawn from school records. Additionally, children's scores on the Dynamic Indicators of Basic Early Literacy Skills (DIBELS) test, (i.e., a direct assessment of phonetic awareness, alphabetic principles, reading comprehension, and vocabulary) were drawn from school records as a baseline measure of literacy skills at kindergarten entry. The DIBELS has strong concurrent and predictive validity with the Woodcock-Johnson battery (Good \& Kaminski, 2002).

The classroom average of particular student characteristics has shown unique influence on outcomes beyond individual-level characteristics (e.g., Henry \& Rickman, 2007), and the influences of teachers' demographic characteristics and overall classroom climate on children's developmental outcomes are well documented (La Paro et al., 2009; Wayne \& Young, 2009). Thus, to account for potential contextual effects, we included the classroom average of children's EC and DIBELS scores (i.e., the mean of all participating children's scores) as covariates. In addition, models controlled for teacher characteristics, including negative affect (19 items, $\alpha=$ .81 ) and surgency (10 items, $\alpha=.85$ ) assessed using the ATQ-Short (Evans \& Rothbart, 2007), as well as teachers' years of teaching experience. Finally, we included quality indicators of classroom climate, using trained observers' ratings of emotional support, classroom organization, and instructional support assessed using the Classroom Assessment Scoring System (CLASS; Pianta, LaParo, \& Hamre, 2008). 


\subsection{Analytic Plan}

We estimated multilevel regression models in Mplus 7 (Muthen \& Muthen, 1998-2012) using full information maximum likelihood to handle missing data, which minimizes bias in parameter estimates while retaining the original sample size (Enders, 2013). Models were specified using TYPE = TWOLEVEL to account for the hierarchical nature of the data (i.e., children [Level 1] nested within classrooms [Level 2]). As such, children's characteristics, including negative affect, surgency, sex, and age, were all analyzed at Level 1, whereas classroom averages of EC and DIBELS scores, teacher characteristics (i.e., years of experience, negative affect, surgency), and classroom climate indicators (i.e., emotional support, classroom organization, instructional support) were analyzed at Level 2. We conducted three sets of multilevel regressions using dummy-coded membership in child-teacher EC pairings to predict math and reading performance (Model 1), school liking (Model 2), and student-teacher closeness and conflict (Model 3). For each set of outcomes, we estimated four models in which the dummy code for each child-teacher EC pairing was systematically removed to serve as the reference group. To preserve degrees of freedom and maintain parsimony, non-temperamental covariates were removed if they were not significantly related to model outcomes.

The dichotomization of child and teacher EC to create child-level indicators of childteacher EC group membership provided at least two benefits over the analysis of a cross-level interaction between child and teacher EC. First, our approach readily facilitated the comparison of adjustment outcomes across each possible child/teacher EC group $\left(\mathrm{H}_{\mathrm{C}} \mathrm{H}_{\mathrm{T}}\right.$ vs. all others, $\mathrm{H}_{\mathrm{C}} \mathrm{L}_{\mathrm{T}}$ vs. all others, etc.). Second, by keeping the EC pairing indicator at the child level, our approach maximized statistical power to detect differences in outcomes across groups, which would be 
severely limited when testing a cross-level interaction with such a small number of level-2 clusters (i.e., 11 classrooms).

\section{Results}

\subsection{Preliminary Analyses}

Significant zero-order correlations between child EC and all outcomes and teacher EC and the academic outcomes justified further exploration of our research questions (see Table 2). Interestingly, teacher EC was not correlated with student-teacher relationship closeness or conflict. Age was not significantly correlated with any of the outcomes and was omitted from regression models.

To further elucidate characteristics of the child-teacher EC groups, we examined differences between groups on potential covariates, as well as group cell sizes and EC means and standard deviations (Table 3). Children in the $\mathrm{H}_{\mathrm{C}} \mathrm{H}_{\mathrm{T}}$ group had higher DIBELS scores at school start than children in the $\mathrm{H}_{\mathrm{C}} \mathrm{L}_{\mathrm{T}}$ or $\mathrm{L}_{\mathrm{C}} \mathrm{L}_{\mathrm{T}}$ groups, were in classrooms with higher average $\mathrm{EC}$ than those in other groups, and had teachers with more years of experience, compared to all other groups. These differences further justified our consideration of these variables as statistical controls in regression models.

Histograms revealed a ceiling effect for school liking and closeness, and floor effect for conflict, with $18 \%$ and $37 \%$ of students receiving the highest possible score on school liking and closeness, respectively, and $26 \%$ receiving the lowest possible score on conflict. Therefore, we employed the Mplus (Muthen \& Muthen, 1998-2012) CENSORED command, which treats ceiling and floor scores as a lower or upper bound estimate of the individual's true score.

\subsection{Multilevel Regression Analyses}


For demonstration purposes, Table 4 presents an example set of regression results utilizing $\mathrm{H}_{\mathrm{C}} \mathrm{H}_{\mathrm{T}}$ as the reference group. Significant differences between other pairs are presented in text only.

\subsubsection{Basic Math}

Children in the $\mathrm{H}_{\mathrm{C}} \mathrm{H}_{\mathrm{T}}$ and $\mathrm{H}_{\mathrm{C}} \mathrm{L}_{\mathrm{T}}$ groups demonstrated better performance in math than children in the $\mathrm{L}_{\mathrm{C}} \mathrm{H}_{\mathrm{T}}(\gamma=-12.43, p<.001, \beta=-.77 ; \gamma=-10.01, p<.001, \beta=-.62$, respectively), and $\mathrm{L}_{\mathrm{C}} \mathrm{L}_{\mathrm{T}}(\gamma=-9.88, p=.005, \beta=-.62 ; \gamma=-8.15, p<.001, \beta=-.51$, respectively) groups (Figure 1, Panel A). Child and average classroom literacy skills at kindergarten entry $(\gamma=.28, p<.001, \beta$ $=.43 ; \gamma=.29, p=.019, \beta=.45$, respectively $)$, and classroom organization $(\gamma=4.87, p=.016, \beta$ $=.34)$ were also significantly related to math scores.

\subsubsection{Basic Reading}

Children in the $\mathrm{H}_{\mathrm{C}} \mathrm{H}_{\mathrm{T}}$ group demonstrated higher reading scores than children in $\mathrm{L}_{\mathrm{C}} \mathrm{H}_{\mathrm{T}}(\gamma$ $=-14.72, p<.001, \beta=-.56)$ and $\mathrm{L}_{\mathrm{C}} \mathrm{L}_{\mathrm{T}}(\gamma=-16.11, p=.018, \beta=-.62)$ groups (Figure 1, Panel $\left.\mathrm{B}\right)$. Reading scores were positively predicted by both child- $(\gamma=.68, p<.001, \beta=.63)$ and average classroom literacy skills at kindergarten entry $(\gamma=.75, p=.001, \beta=.73)$, and teacher years of experience $(\gamma=1.33, p=.010, \beta=.81)$, but negatively predicted by teacher negative affect $(\gamma=-$ $6.92, p=.038, \beta=-.38)$ and average classroom $\mathrm{EC}(\gamma=-15.85, p=.004, \beta=-.47)$.

\subsubsection{School liking.}

Children in the $\mathrm{H}_{\mathrm{C}} \mathrm{H}_{\mathrm{T}}$ group reported more school liking than children in the $\mathrm{H}_{\mathrm{C}} \mathrm{L}_{\mathrm{T}}(\gamma=$ $.19, p=.026, \beta=-.47), \mathrm{L}_{\mathrm{C}} \mathrm{H}_{\mathrm{T}}(\gamma=-.32, p<.001, \beta=-.78)$, and $\mathrm{L}_{\mathrm{C}} \mathrm{L}_{\mathrm{T}}(\gamma=-.39, \mathrm{p}=.001, \beta=-.95)$ groups (Figure 1, Panel C). School liking was positively predicted by average classroom EC ( $\gamma=$ $.19, p<.001, \beta=.71)$ and classroom emotional support $(\gamma=.15, p=.014, \beta=.68)$, but 
negatively predicted by child negative affect $(\gamma=-.08, p=.017, \beta=-.18)$ and teacher surgency $(\gamma$ $=-.05, p=.046, \beta=-.46)$.

\subsubsection{Student-teacher relationship closeness.}

Children in the $\mathrm{L}_{\mathrm{C}} \mathrm{H}_{\mathrm{T}}$ group had less-close relationships with their teachers compared to children in the $\mathrm{H}_{\mathrm{C}} \mathrm{H}_{\mathrm{T}}(\gamma=1.16, p<.001, \beta=1.21), \mathrm{H}_{\mathrm{C}} \mathrm{L}_{\mathrm{T}}(\gamma=1.60, p=.005, \beta=1.66)$, and $\mathrm{L}_{\mathrm{C}} \mathrm{L}_{\mathrm{T}}$ $(\gamma=1.58, p=.015, \beta=1.64)$ groups (Figure 2, Panel A). Girls tended to have closer teacher relationships than boys $(\gamma=-.57, p=.016, \beta=-.59)$.

\subsubsection{Student-teacher relationship conflict.}

Children in the $\mathrm{L}_{\mathrm{C}} \mathrm{H}_{\mathrm{T}}$ group had more conflictual relationships with their teachers than children in the $\mathrm{H}_{\mathrm{C}} \mathrm{H}_{\mathrm{T}}(\gamma=-.96, p=.002, \beta=-.77), \mathrm{H}_{\mathrm{C}} \mathrm{L}_{\mathrm{T}}(\gamma=-1.55, p<.000, \beta=-1.24)$, and $\mathrm{L}_{\mathrm{C}} \mathrm{L}_{\mathrm{T}}(\gamma=-1.35, p=.038, \beta=-1.08)$ groups (Figure 2, Panel B). Conflict was positively predicted by child negative affect $(\gamma=.63, p<.001, \beta=.51)$ and child surgency $(\gamma=.28, p<$ $.001, \beta=.25)$, and negatively predicted by instructional support $(\gamma=-.59, p=.033, \beta=-.38)$, Boys tended to have more conflict in their relationships with teachers than girls $(\gamma=.51, p=$ $.006, \beta=.41)$.

\section{Discussion}

To our knowledge, this study is the first to examine how kindergartners' EC influences their academic and relational adjustment in the context of the EC of an important socializing agent - the kindergarten teacher. Two distinct patterns of findings emerged, suggesting different child-teacher EC pairings were particularly beneficial or detrimental for different types of outcomes. For academic outcomes including basic math, basic reading, and school liking, children in pairings in which both they and their teacher were high in EC fared the best. In contrast, for student-teacher relationship closeness and conflict outcomes, children low in EC 
with teachers high in EC emerged as a stand-out group, but not in a good way: Children in this pairing had lower closeness and higher conflict with their teachers than those in other pairings. These findings offer initial evidence regarding how a significant contextual feature of the classroom - teacher EC - can affect how child EC operates on a variety of school-based adjustment outcomes.

\subsection{Academic Performance and School Liking Outcomes}

For math and reading, children in the $\mathrm{H}_{\mathrm{C}} \mathrm{H}_{\mathrm{T}}$ group scored higher than all groups except $\mathrm{H}_{\mathrm{C}} \mathrm{L}_{\mathrm{T}}$, whereas for school liking, children in the $\mathrm{H}_{\mathrm{C}} \mathrm{H}_{\mathrm{T}}$ group scored higher than those in all the other pairings. These findings suggest the combination of high EC in the child-teacher pairing promoted academic performance above that of low-EC students, and school liking above the level of other high-EC students as well. Taken together, this pattern of results may exemplify the Matthew effect (Merton, 1968) — when the gap between those with and without dispositional or environmental assets grows because individuals who have (i.e., high-EC children) are better positioned to take advantage of environmental affordances (i.e., high teacher EC) relative to those who have not.

We also found that children in the $\mathrm{H}_{\mathrm{C}} \mathrm{L}_{\mathrm{T}}$ group scored significantly higher on math than children who were low in EC, regardless of teachers' EC level. This finding supports the theory that proximal influences (e.g., child's own temperament), exert more influence on development than more distal characteristics of the child's environment (e.g., teacher's temperament;

Bronfenbrenner \& Morris, 2006), and suggests children's own EC appears to be fundamentally_ and discretely_important for math performance. Child EC might be especially important for learning basic mathematical concepts and skills due to the low exposure to math instruction in the early grades, relative to literacy instruction (Bassok \& Rorem, 2014). Higher 
levels of EC may help enable children to focus on and retain math concepts despite abbreviated exposure.

Across the academic models, the outcomes were surprising for the $\mathrm{L}_{\mathrm{C}} \mathrm{L}_{\mathrm{T}}$ pairings. Given the importance of EC for academic performance, we expected children in these pairings to perform worse than their peers; however, for reading and school liking, children in the $\mathrm{L}_{\mathrm{C}} \mathrm{L}_{\mathrm{T}}$ group performed at the same level of those in the $\mathrm{H}_{\mathrm{C}} \mathrm{L}_{\mathrm{T}}$ and $\mathrm{L}_{\mathrm{C}} \mathrm{H}_{\mathrm{T}}$ group, suggesting a matched low-EC pairing was not an added detriment. For math, children in the $\mathrm{L}_{\mathrm{C}} \mathrm{L}_{\mathrm{T}}$ group did not differ from those in the $\mathrm{L}_{\mathrm{C}} \mathrm{H}_{\mathrm{T}}$ group, suggesting that having a high-EC teacher did not foster performance for low-EC students.

\subsection{Student-teacher Relationship Outcomes}

For closeness and conflict, the $\mathrm{H}_{\mathrm{C}} \mathrm{H}_{\mathrm{T}}, \mathrm{H}_{\mathrm{C}} \mathrm{L}_{\mathrm{T}}$, and $\mathrm{L}_{\mathrm{C}} \mathrm{L}_{\mathrm{T}}$ groups did not score significantly different from one another, indicating students and teachers can develop close relationships when (a) children are high in EC, despite the teacher's EC level, or (b) children and teachers are compatible in terms of EC levels, even when the compatibility is on a characteristic typically considered undesirable (i.e., low EC). For children in the $\mathrm{L}_{\mathrm{C}} \mathrm{L}_{\mathrm{T}}$ group, it could be that the relative similarity between child and teacher EC levels acts as a buffer in some ways. The homophily in these pairings may have enhanced the quality of the student-teacher relationships to that of the high-EC children. Our findings support prior work that children's high EC is important for student-teacher relationship quality (Rudasill, 2011), but also demonstrate how child-teacher similarity can result in the formulation of high-quality teacher-student relationships, even for those low in EC.

Overall, findings for the relational outcomes supported a goodness-of-fit—or rather, poorness-of-fit framework. Children in the $\mathrm{L}_{\mathrm{C}} \mathrm{H}_{\mathrm{T}}$ group were consistently rated as having less 
closeness and more conflict with teachers than those in any other group. Because highly regulated teachers would be presumed better able to model regulatory behaviors and inhibit reactionary tendencies, high-EC teachers may be assumed to be a positive factor in the classroom. Our results suggest this is not necessarily the case regarding the quality of studentteacher relationships for low-EC children. It is possible that, compared to teachers low in EC, high-EC teachers may have greater expectations for students' self-regulatory abilities and become frustrated when those expectations are not met. Although theoretically, high-EC teachers should be better able than low-EC teachers to manage the behavioral manifestation of their frustration, our findings suggest high-EC teachers may struggle or be less motivated to develop high-quality relationships with low-EC children.

\subsection{Limitations and Future Directions}

Although the findings presented here are compelling and represent a needed and novel contribution to existing literature, several limitations hinder our ability to generalize broadly. First, our sample of teachers was small and relatively homogenous, consisting of 11 females, 10 of whom identified as European American. The predictive qualities of EC pairings might look different with a larger and more diverse group of teachers. Second, the cross-sectional nature of our study prohibits any causal interpretations regarding relations between child-teacher EC pairings and adjustment outcomes. Relatedly, both child and teacher EC were assessed via teacher report. We acknowledge teachers' reports of their own as well as their students' EC may have been affected by teachers' and students' background and personal characteristics and classroom interactions. This would suggest teachers' training, personality, and children's adjustment outcomes, as examples, could influence teachers' reports of EC. Although we accounted for a number of covariates for their relation to adjustment outcomes, our analytic 
approach did not account for determinants of EC. The use of longitudinal mediation models and alternative reporters of EC is a recommended direction to further elucidate the relations presented here.

The findings indicate several areas for future research. Other temperamental characteristics, including surgency and negative affect, should be explored to further understand how child and teacher temperaments dynamically interact to influence school adjustment. Additionally, children's EC could be examined in relation to peer EC. Using larger sample sizes, researchers can examine moderators and mediators of relations between child and teacher EC pairings and school outcomes. Examination of potential moderating child characteristics known to correlate with EC such as sex would appear particularly useful in illuminating whether and how children are differentially affected by teachers' EC. The identification of mediating mechanisms may also provide insight into malleable classroom processes more readily enhanced through intervention than individuals' EC.

\subsection{Implications and Conclusion}

These preliminary results suggest methods of enhancing kindergarten adjustment via teacher training or professional development. By learning about and reflecting on students' and their own temperamental characteristics - and how these function in concert, teachers may become more aware of how attributes like EC shape their classroom practices and interactions with students. They also may be better able to identify and address temperamental differences among children within the classroom. For example, high-EC teachers might find strategies to improve their relationships with low-EC children, such as spending more time with these students, working with these students to improve self-regulatory competence, or recalibrating their perceptions of these children based on other areas of competence. Low-EC teachers may 
gain insight into how their own characteristics differentially affect the math performance of highand low-EC students. Alternatively, children low in EC may benefit from additional math instruction when paired with a low-EC teacher.

In closing, the results of this novel study revealed nuances in the relation between child EC and early school success. We provide new evidence regarding how the benefits associated with children's EC may be enhanced or mitigated depending on their kindergarten teacher's EC, highlighting promising directions for research considering children's EC and other temperamental characteristics in conjunction with those of key socializers. 


\section{Acknowledgements}

Authors' Notes: This material is based upon work supported by the National Science

Foundation, through funding provided to the first author, under Grant No. DGE-131123.

Additional support was provided by the T. Denny Sanford School of Social and Family

Dynamics as part of the Kindergarten Project (http://kindergartenproject.org) and the Arizona

State University Cowden Endowment. The opinions expressed are those of the authors and do not represent views of the National Science Foundation, T. Denny Sanford School of Social and Family Dynamics, or Cowden Endowment. An earlier version of this paper was presented at the American Education Research Association annual meeting in Philadelphia, PA in April 2014. 


\section{References}

Barbarin, O. A., Downer, J., Odom, E., \& Head, D. (2010). Home-school differences in beliefs, support, and control during public pre-kindergarten and their link to children's kindergarten readiness. Early Childhood Research Quality, 25, 358-372. doi:

10.1016/j.ecresq.2010.02.003

Bassok, D., \& Rorem, A. (2014). Is Kindergarten the new first grade? The changing nature of Kindergarten in the age of accountability. EdPolicyWorks Working Paper Series, No. 20. Retrieved from: http://curry.virginia.edu/uploads/resourceLibrary/ 20_Bassok_Is_Kindergarten_The_New_First_Grade.pdf

Blair, C., \& Razza, R. P. (2007). Relating effortful control, executive function, and false belief understanding to emerging math and literacy ability in Kindergarten. Child Development, 78(2), 647-663. doi:10.1111/j.1467-8624.2007.01019.x

Blair, K., Deham, S., Kochanoff, A., \& Whipple, B. (2004). Playing it cool: Temperament, emotion regulation, and social behavior in preschoolers. Journal of School Psychology, 42(6), 419-443. doi: 10.1016/j.jsp.2004.10.002

Bronfenbrenner, U. \& Morris, P. A. (2006). The bioecological model of human development. In W. Damon \& R. M. Lerner (Eds.), Handbook of child psychology, Vol. 1: Theoretical models of human development (6 ${ }^{\text {th }}$ ed., pp. 793-828). New York: John Wiley.

Brown, J. L., Jones, S. M., LaRusso, M. D., \& Aber, J. L. (2010). Improving classroom quality: Teacher influences and experimental impacts of the 4Rs program. Journal of Educational Psychology, 102(1), 153-167. doi: 10.1037/a0018160

Carlson, S.M. (2005). Developmentally sensitive measures of executive function in preschool children. Developmental Neuropsychology, 28, 595-616. 
Conduct Problems Prevention Research Group. (1999). Initial impact of the Fast Track prevention trial for conduct problems: II. Classroom effects, Journal of Consulting and Clinical Psychology, 67(5), 648-657. doi:10.1037//0022-006x.67.5.648

Cumberland-Li, A., Eisenberg, N., \& Reiser, M. ( 2004). Relations of young children's agreeableness and resiliency to effortful control and impulsivity. Social Development, 13, 193-212. doi:10.1111/j.1467-9507.2004.000263.x

Duncan, G. J., Dowsett, C. J., Claessens, A., Magnuson, K., Huston, A. C., Klebanov, P.,...Japel, C. (2007). School readiness and later achievement. Developmental Psychology, 43(6), 14281446. doi:10.1037/0012-1649.43.6.1428.

Early, D. M., Pianta, R. C., \& Cox, M. J. (1999). Kindergarten teachers and classrooms: A transition context. Early Education and Development, 10(1), 25-46. doi:10.1207/s15566935eed1001_3

Enders, C. K. (2013). Dealing with missing data in developmental research. Child Development Perspectives, 7, 27-31. doi:10.111/cdep.12008

Evans, D.E., \& Rothbart, M.K. (2007). Development of a model for adult temperament. Journal of Research in Personality, 41, 868-888. doi: 10.1016/j.jrp.2006.11.002

Good, R. H., \& Kaminski, R. A. (Eds.). (2002). Dynamic indicators of basic early literacy skills (6th ed.). Eugene, OR: Institute for the Development of Educational Achievement. http://dibels.uoregon.edu/.

Hamre, B. K., \& Pianta, R. C. (2001). Early teacher-child relationships and the trajectory of children's school outcomes through eighth grade. Child Development, 72(2), 625-638. doi:10.111/1467-8624.00301 
Hamre, B. K., \& Pianta, R. C. (2005). Can instructional and emotional support in the first-grade classroom make a difference for children at risk of school failure? Child Development, 76(5), 949-967. doi:10.1111/j.1467-8624.2005.00889.x

Henry, G. T., \& Rickman, D. K. (2007). Do peers influence children's skill development in preschool? Economics of Education Review, 26, 100-112.

doi:10.1016/j.econedurev.2005.09.006

Iyer, R. V., Kochenderfer-Ladd, B., Eisenberg, N. \& Thompson, M. (2010). Peer victimization and effortful control: Relations to school engagement and academic achievement. Merrill Palmer Quarterly, 56(3), 361-287. doi: 10.1353/mpq.0.0058

Keogh, B. K. (2003). Temperament in the Classroom: Understanding Individual Differences. Balitmore, MD: Paul H. Brooks.

Kochanska, G., Murray, K. T., \& Harlan, E. T. (2000). Effortful control in early childhood: continuity and change, antecedents, and implications for social development. Developmental Psychology, 36(2), 220-232. doi:10.1037/0012-1649.36.2.220

Ladd, G. W. \& Price, J. M. (1987). Predicting children's social and school adjustment following the transition from preschool to kindergarten. Child Development, 58, 1168-1189. doi: $10.2307 / 1130613$

Love, J. M., Logue, M. E., Trudeau, J. V., \& Thayer, K. (1992). Transitions to kindergarten in American schools (Contract No. LC 88089001). Portsmouth, NH: U.S. Department of Education.

McClelland, M. M., Acock, A. C., \& Morrison, F. J. (2006). The impact of kindergarten learning-related skills on academic trajectories at the end of elementary school. Early Childhood Research Quarterly, 21, 471-490. doi: 10.1016/j.ecresq.2006.09.003 
Morrison, F. J., \& Connor, C. M. (2002). Understanding schooling effects on early literacy: A working research strategy. Journal of School Psychology, 40(6), 493-500. doi:10.1016/s0022-4405(02)00127-9

Merton, R. K. (1968). The Matthew Effect in science. Science, 159(3810), 56-63. doi:10.1126/science.159.3810.56

Muthén, L. K., \& Muthén, B. O. (1998-2012). Mplus user's guide (6th ed.). Los Angeles: Muthén \& Muthén.

NICHD Early Child Care Research Network. (2003). Do children's attention processes mediate the link between family predictors and school readiness? Developmental Psychology, 39, 581-593. doi:10.1037/0012-1649.39.3.581

Olson, S. L., Sameroff, A. J., Kerr, D. C., Lopez, N. L., \& Wellman, H. M. (2005). Developmental foundations of externalizing problems in young children: The role of effortful control. Development and Psychopathology, 17(1), 25-45. doi:10.1017/s0954579405050029

Pianta, R. C. (2001). STRS Student-teacher Relationship Scale: Professional Manual. Psychological Assessment Resources.

Pianta, R. C., La Paro, K., \& Hamre, B. K. (2008). Classroom Assessment Scoring System (CLASS). Balitmore: Paul H. Brookes.

Posner, M. I., \& Rothbart, M. K. (2000). Developing mechanisms of self-regulation. Development and Psychopathology, 12(3), 427-441. doi:10.1017/s0954579400003096

Putnam, S. P., \& Rothbart, M. K. (2006). Development of Short and Very Short forms of the Children's Behavior Questionnaire. Journal of Personality Assessment, 87 (1), 103-113. doi:10.1207/s15327752jpa8701_09 
Raver, C. C. (2002). Emotion matter: Making the case for the role of young children's emotional development or early school readiness. Social Policy Report, 16(3), 3-18.

Raver, C. C., Blair, C., \& Li-Grining, C. P. (2012). Extending models of emotion self-regulation to classroom settings: Implications for professional development. In C. Howes, B. K. Hamre \& R. C. Pianta (Eds.), Effective early childhood professional development: Improving teacher practice and child outcomes (pp. 113-130). Baltimore, MD: Paul H. Brookes Publishing Company.

Rimm-Kaufman, S. E., Pianta, R. C., \& Cox, M. J. (2000). Teachers' judgments of problems in the transition to kindergarten. Early Childhood Research Quarterly, 15(2), 147-166. doi:10.1016/s0885=2006(00)00049-1

Rimm-Kaufman S. E., \& Pianta, R. C. (2000). An ecological perspective on the transition to kindergarten: A theoretical framework to guide empirical research. Journal of Applied Developmental Psychology, 21(5), 491-511. doi:10.1016/s0193-3973(00)00051-4

Rimm-Kaufman, S. E., Early, D., Cox, M., Saluja, G., Pianta, R., Bradley, R., \& Payne, C. (2002). Early behavioral attributes and teachers' sensitivity as predictors of competent behavior in the kindergarten classroom. Journal of Applied Developmental Psychology, 23, 451- 470. doi:10.1016/s0193-3973(02)00128-4

Rothbart, M. K., \& Bates, J. E. (2006). Temperament. In W. Damon (Series Ed.) \& N. Eisenberg (Vol. Ed.), Handbook of child psychology: Vol. 3. Social, emotional and personality development (6th ed., pp. 99-166). New York: Wiley.

Rothbart, M. K., \& Jones, L. B. (1998). Temperament, self regulation, and education. School Psychology Review, 27, 479-491.

Rudasill, K. M. (2011). Child temperament, teacher-child interactions, and teacher-child 
relationships: A longitudinal investigation from first to third grade. Early Childhood Research Quarterly, 26, 147-156. doi: 10.1016/j.ecresq.2010.07.002

Rudasill K. M., \& Rimm-Kaufman, S. E. (2009). Teacher-child relationship quality: The roles of child temperament and teacher-child interactions. Early Childhood Research Quarterly, 24, 107-120. doi:10.1016/j.ecresq.2008.12.003

Rudasill, K. M., Niehaus, K., Buhs, E., \& White, J. M. (2013). Temperament in early childhood and peer interactions in third grade: The role of teacher-child relationships in early elementary grades. Journal of School Psychology, 51, 701-716. doi: 10.1016/j.jsp.2013.08.002

Sektnan, M., McClelland, M. M., Acock, A., \& Morrison, F. J. (2010). Early family risk, behavioral regulation, and children's academic achievement. Early Childhood Research Quarterly, 25(4), 464-479. doi:10.1016/j.ecresq.2010.02.005

Sutton, R. E., \& Wheatley, K. F. (2003). Teachers' emotions and teaching: A review of the literature and directions for future research. Educational Psychology Review, 15, 327-358.:

Swanson, J., Valiente, C., \& Lemery-Chalfant, K. (2012). Predicting academic achievement from cumulative home risk: The mediating roles of effortful control, academic relationships, and school avoidance. Merrill-Palmer Quarterly, 58(3), 375-408.

Thomas, A., \& Chess, S. (1977). Temperament and development. New York: Brunner/Mazel.

Valiente, C., Lemery-Chalfant, K. \& Swanson, J. (2010). Prediction of kindergarteners' academic achievement from their effortful control and emotionality: Evidence for direct and moderated relations. Journal of Educational Psychology, 102(3), 550-560. doi:10.1037/a0018992

Valiente, C., Lemery-Chalfant, K., Swanson, J., \& Reiser, M. (2008). Prediction of children's 
academic competence from their effortful control, relationships, and classroom participation. Journal of Educational Psychology, 100(1), 67-77. doi: 10.1037/0022-0663.100.1.67.

Valiente, C., Eisenberg, N., Haugen, R., Spinrad, T. L., Hofer, C., Liew, J., \& Kupfer, A. (2011). Children's Effortful Control and Academic Achievement: Mediation Through Social Functioning. Early Education and Development, 22(3), 411-433.

doi:10.1080/10409289.2010.505259

Wachs, T. D. (2000). Necessary but not sufficient: The respective roles of single and multiple influences on individual development. Washington, D.C.: American Psychological Association.

Woodcock, R. W., McGrew, K. S., \& Mather, N. (2001-2007). Woodcock-Johnson III: Tests of achievement. Itasca, IL: Riverside.

Zetner, M. \& Bates, J. E., (2008). Child temperament: An integrative review of concepts, research programs, and measures. European Journal of Developmental Science, 2(1/2), 7-37. 
Table 1

Sample characteristics

Child demographics $(n=174)$

Female

Age

Ethnicity

Caucasian

Hispanic/Latino

Asian

African American

Other/Mixed Ethnicity

Family income

$\$ 39,000$ or less

$\$ 40,000-\$ 79,000$

$\$ 80,000$ or more

$51 \%$

$\mathrm{M}=6.48, S D=.34$

Primary caregiver education

High school diploma or less

Some college

$60 \%$

$29 \%$

$5 \%$

$2 \%$

$4 \%$

Bachelor's degree

Graduate degree

$28 \%$

$20 \%$

$52 \%$

$19.1 \%$

$33.6 \%$

$32.1 \%$

$15.2 \%$

Teacher demographics $(n=11)$

Female

$100 \%$

Ethnicity

Caucasian

$90.9 \%$

African America

$1.1 \%$

Education

Bachelor's degree

$54.5 \%$

Master's degree

$45.4 \%$

Years of experience

$\mathrm{M}=10.44, S D=8.26$ 
Table 2

Correlations and descriptive statistics for predictors and outcomes

\begin{tabular}{|c|c|c|c|c|c|c|c|c|c|c|}
\hline & Basic math & Basic reading & School liking & Closeness & Conflict & $N$ & M & $S D$ & Min & Max \\
\hline \multicolumn{11}{|l|}{ Child predictors } \\
\hline $\mathrm{EC}$ & $0.38^{* *}$ & $0.37^{* *}$ & $0.29^{* *}$ & $0.46^{* *}$ & $-0.34^{* *}$ & 174 & 4.85 & 0.91 & 1.00 & 6.75 \\
\hline NA & $-0.23^{* *}$ & $-0.29^{* *}$ & $-0.20^{* *}$ & 0.00 & $0.46^{* *}$ & 174 & 3.71 & 1.01 & 1.55 & 6.75 \\
\hline Surgency & 0.00 & 0.05 & 0.00 & -0.03 & $0.35^{* *}$ & 174 & 4.47 & 1.12 & 1.75 & 7.25 \\
\hline Gender & -0.02 & -0.08 & -0.04 & $-0.30^{* *}$ & $0.28^{* *}$ & 173 & 0.48 & 0.50 & 0.00 & 1.00 \\
\hline DIBELS & $0.52^{* *}$ & $0.67^{* *}$ & $0.37^{* *}$ & 0.06 & $-0.17^{*}$ & 152 & 34.84 & 27.07 & 0.00 & 110.00 \\
\hline Age & 0.11 & 0.09 & 0.06 & -0.05 & 0.07 & 173 & 6.48 & 0.34 & 5.63 & 7.51 \\
\hline \multicolumn{11}{|l|}{ Classroom Predictors } \\
\hline Teacher EC & $0.31^{* *}$ & $0.25^{* *}$ & $0.29^{* *}$ & 0.02 & 0.05 & 11 & 4.41 & 0.79 & 2.72 & 5.61 \\
\hline Teacher NA & -0.05 & $-0.21^{* *}$ & 0.08 & 0.02 & 0.13 & 11 & 3.47 & 0.76 & 2.53 & 4.63 \\
\hline Teacher surgency & -0.11 & -0.09 & -0.13 & 0.11 & 0.02 & 11 & 5.00 & 1.02 & 2.90 & 6.00 \\
\hline Teacher experience & $0.38^{* *}$ & $0.36^{* *}$ & $0.34^{* *}$ & -0.03 & -0.07 & 11 & 10.44 & 8.26 & 1.00 & 25.00 \\
\hline Classroom EC & $0.28^{* *}$ & $0.23^{* *}$ & $0.25^{* *}$ & $0.22^{* *}$ & -0.08 & 11 & 4.86 & 0.41 & 3.85 & 5.41 \\
\hline $\begin{array}{l}\text { Classroom } \\
\text { organization }\end{array}$ & $0.29 * *$ & $0.21 * *$ & $0.18 *$ & -0.04 & -0.07 & 11 & 5.43 & 0.78 & 3.50 & 6.50 \\
\hline Emotional support & $0.16^{*}$ & 0.13 & $0.16^{*}$ & -0.01 & -0.11 & 11 & 5.39 & 0.55 & 4.31 & 6.31 \\
\hline $\begin{array}{l}\text { Instructional } \\
\text { support }\end{array}$ & $0.15^{*}$ & $0.20 * *$ & 0.13 & 0.12 & $-0.15^{*}$ & 11 & 2.33 & 0.47 & 1.58 & 3.58 \\
\hline$N$ & 170 & 170 & 171 & 175 & 175 & & & & & \\
\hline M & 442.39 & 402.36 & 1.50 & 4.34 & 1.83 & & & & & \\
\hline$S D$ & 19.21 & 32.15 & 0.38 & 0.74 & 1.00 & & & & & \\
\hline Min & 350.00 & 326.00 & 0.57 & 1.00 & 1.00 & & & & & \\
\hline Max & 507.00 & 497.00 & 2.00 & 5.00 & 4.75 & & & & & \\
\hline
\end{tabular}

Note. $\mathrm{EC}=$ Effortful Control, NA= Negative Affect, DIBELS = Dynamic Indicators of Basic Early Learning Skills $* p<.05, * * \mathrm{p}<.01$ 
Table 3

Mean differences between EC groups

\begin{tabular}{|c|c|c|c|c|c|c|c|c|c|}
\hline & \multicolumn{2}{|c|}{$\begin{array}{c}\mathrm{H}_{\mathrm{C}} \mathrm{H}_{\mathrm{T}}^{\mathrm{a}} \\
n=113^{1}(45 \% \text { male })\end{array}$} & \multicolumn{2}{|c|}{$\begin{array}{c}\mathrm{H}_{\mathrm{C}} \mathrm{L}_{\mathrm{T}}^{\mathrm{b}} \\
n=40(38 \% \text { male })\end{array}$} & \multicolumn{2}{|c|}{$\begin{array}{c}\mathrm{L}_{\mathrm{C}} \mathrm{H}_{\mathrm{T}}{ }^{\mathrm{c}} \\
n=12(100 \% \text { male })\end{array}$} & \multicolumn{2}{|c|}{$\begin{array}{c}\mathrm{L}_{\mathrm{C}} \mathrm{L}_{\mathrm{T}}^{\mathrm{d}} \\
n=9(56 \% \text { male })\end{array}$} & \multirow[t]{2}{*}{$\mathrm{F}(\mathrm{p})$} \\
\hline & M & $S D$ & M & $S D$ & M & $S D$ & M & $S D$ & \\
\hline \multicolumn{10}{|l|}{ Grouping variables } \\
\hline Child EC & $5.14^{\mathrm{c}, \mathrm{d}}$ & 0.66 & $4.87^{\mathrm{c}, \mathrm{d}}$ & 0.73 & $3.26^{\mathrm{a}, \mathrm{b}}$ & 0.53 & $3.26^{\mathrm{a}, \mathrm{b}}$ & 0.92 & $45.310(<.001)$ \\
\hline Teacher EC & $4.84^{\mathrm{b}, \mathrm{d}}$ & 0.39 & $3.40^{\mathrm{a}, \mathrm{c}}$ & 0.51 & $4.74^{\mathrm{b}, \mathrm{d}}$ & 0.51 & $3.34^{\mathrm{a}, \mathrm{c}}$ & 0.60 & $123.604(<.001)$ \\
\hline \multicolumn{10}{|l|}{ Child covariates } \\
\hline NA & 3.68 & 1.06 & 3.82 & 0.71 & 3.29 & 1.21 & 4.18 & 1.06 & $1.567(.199)$ \\
\hline Surgency & 4.52 & 1.18 & 4.34 & 0.95 & 4.00 & 1.08 & 5.02 & 0.90 & $1.704(.168)$ \\
\hline Gender & $0.45^{\mathrm{c}}$ & 0.50 & $0.39^{c}$ & 0.50 & $1.00^{\mathrm{a}, \mathrm{b}}$ & 0.00 & 0.56 & 0.53 & $5.223(.002)$ \\
\hline Age & 6.49 & 0.35 & 6.48 & 0.35 & 6.36 & 0.27 & 6.57 & 0.38 & $0.705(.550)$ \\
\hline DIBELS & $39.83^{\mathrm{d}}$ & 27.10 & $25.39^{\mathrm{a}}$ & 24.78 & 30.80 & 26.23 & $13.00^{\mathrm{a}}$ & 16.63 & $4.759(.003)$ \\
\hline \multicolumn{10}{|l|}{ Classroom covariates } \\
\hline Teacher NA & $3.39^{\mathrm{b}}$ & 0.64 & $3.80^{\mathrm{a}, \mathrm{c}}$ & 0.96 & $3.17^{\mathrm{b}}$ & 0.50 & 3.56 & 0.99 & $3.781(.012)$ \\
\hline Teacher surgency & 4.95 & 1.15 & 5.04 & 0.67 & 5.57 & 0.69 & 4.78 & 0.59 & $1.517(.212)$ \\
\hline Teacher experience & $13.60^{\mathrm{b}, \mathrm{c}, \mathrm{d}}$ & 8.22 & $3.68^{\mathrm{a}}$ & 3.24 & $7.92^{\mathrm{a}}$ & 6.29 & $4.44^{\mathrm{a}}$ & 3.40 & $22.372(<.001)$ \\
\hline Classroom EC & $5.00^{\mathrm{b}, \mathrm{c}, \mathrm{d}}$ & 0.33 & $4.59^{\mathrm{a}}$ & 0.41 & $4.64^{\mathrm{a}}$ & 0.35 & $4.52^{\mathrm{a}}$ & 0.51 & $17.182(<.001)$ \\
\hline
\end{tabular}

Note. EC = Effortful Control, NA = Negative Affect, DIBELS = Dynamic Indicators of Basic Early Learning Skills, T = Teacher;

Subscripts delineate mean differences between groups.

\footnotetext{
${ }^{1}$ Because cell sizes were uneven between the four groups, we also examined results from analyses conducted using the median, rather than scale midpoint, as the low/high dichotomization point. The pattern of results was similar. Given the limitations associated with use of the median, we report results from the models using the scale midpoint.
} 
Table 4

Example regression table using $H_{C} H_{T}$ as the reference group for all outcomes

\begin{tabular}{|c|c|c|c|c|c|c|c|c|c|c|c|c|c|c|c|}
\hline & \multicolumn{3}{|c|}{ Basic math } & \multicolumn{3}{|c|}{ Basic reading } & \multicolumn{3}{|c|}{ School liking } & \multicolumn{3}{|c|}{ Closeness } & \multicolumn{3}{|c|}{ Conflict } \\
\hline & $\mathrm{B}$ & $S E$ & $\beta$ & $\mathrm{B}$ & $S E$ & $\beta$ & $\mathrm{B}$ & $S E$ & $\beta$ & $\mathrm{B}$ & $S E$ & $\beta$ & $\mathrm{B}$ & $S E$ & $\beta$ \\
\hline \multicolumn{16}{|l|}{ EC Groups } \\
\hline $\mathrm{H}_{\mathrm{c}} \mathrm{L}_{\mathrm{t}}$ & -1.07 & 2.89 & -.07 & -8.75 & 6.05 & -.34 & $-.19 *$ & .09 & -.47 & .44 & .51 & .46 & -.60 & .39 & -.48 \\
\hline $\mathrm{L}_{\mathrm{c}} \mathrm{H}_{\mathrm{t}}$ & $-12.34 * *$ & 2.15 & -.77 & $-14.72 * *$ & 3.50 & -.56 & $-.32 * *$ & .06 & -.78 & $-1.16^{* *}$ & .31 & -1.21 & $.28 * *$ & .06 & .77 \\
\hline $\mathrm{L}_{\mathrm{c}} \mathrm{L}_{\mathrm{t}}$ & $-9.88 * *$ & 3.53 & -.62 & $-16.11 * *$ & 6.80 & -.62 & $-.39 * *$ & .11 & -.95 & .42 & .61 & .44 & -.39 & .61 & -.32 \\
\hline \multicolumn{16}{|l|}{ Child Covariates } \\
\hline NA & .52 & 1.45 & .03 & -.63 & 1.64 & -.02 & $-.08 *$ & .03 & -.18 & -.17 & .10 & -.18 & $.63 * *$ & .12 & .51 \\
\hline Surg & -.20 & 1.09 & -.01 & .36 & 1.04 & .02 & .03 & .04 & .08 & .02 & .05 & .02 & $.28 * *$ & .06 & .25 \\
\hline Sex & -- & -- & -- & -- & -- & -- & -- & -- & -- & $-.57 *$ & .24 & -.59 & $.51 * *$ & .19 & .41 \\
\hline DIBELS & $.26 * *$ & .04 & .43 & $.68 * *$ & .08 & .63 & -- & -- & -- & -- & -- & -- & -- & -- & -- \\
\hline \multicolumn{16}{|c|}{ Classroom Covariates } \\
\hline T NA & -1.86 & 1.73 & -.12 & $-6.92 *$ & 3.34 & -.38 & .06 & .04 & .39 & -.13 & .22 & -.14 & .28 & .14 & .32 \\
\hline T Surg & -.43 & 2.48 & .33 & 5.63 & 4.55 & .41 & $-.05 *$ & .03 & -.46 & .23 & .14 & .33 & -.17 & .13 & -.29 \\
\hline $\mathrm{T}$ Experience & .35 & .31 & .82 & $1.33^{*}$ & .51 & .81 & -- & -- & -- & -- & -- & -- & -- & -- & -- \\
\hline CL EC & 3.88 & 3.60 & -.22 & $-15.85 * *$ & 5.55 & -.47 & $.19 * *$ & .05 & .71 & .63 & .35 & .37 & -.53 & .07 & -.57 \\
\hline CL DIBELS & $.29 *$ & .13 & .45 & $.75^{* *}$ & .23 & .73 & -- & -- & -- & -- & -- & -- & & & \\
\hline CL CO & $4.87 *$ & 2.01 & .34 & -3.00 & 4.27 & -.15 & -- & -- & -- & -- & -- & -- & & & \\
\hline CL ES & -- & -- & -- & -- & -- & -- & $.15^{*}$ & .06 & .68 & -- & -- & -- & & & \\
\hline \multirow[t]{2}{*}{ CL IS } & -- & -- & -- & -- & -- & -- & -- & -- & -- & .65 & .38 & -.57 & $-.59 *$ & .28 & -.38 \\
\hline & \multicolumn{2}{|c|}{$\begin{array}{c}\chi^{2} d f \\
9.5710\end{array}$} & $\begin{array}{c}R^{2} \\
.23^{* *}\end{array}$ & \multicolumn{2}{|c|}{$\begin{array}{c}\chi^{2} d f \\
9.5710\end{array}$} & $\begin{array}{c}R^{2} \\
.45^{* *}\end{array}$ & \multicolumn{2}{|c|}{$\begin{array}{l}\chi^{2} d f \\
6.496\end{array}$} & $\begin{array}{c}R^{2} \\
.13^{*}\end{array}$ & \multicolumn{2}{|c|}{$\begin{array}{c}\chi^{2} d f \\
8.868\end{array}$} & $\begin{array}{c}R^{2} \\
.31^{* * *}\end{array}$ & \multicolumn{2}{|c|}{$\begin{array}{c}\chi^{2} d f \\
8.868\end{array}$} & $\begin{array}{c}R^{2} \\
.52^{* * *}\end{array}$ \\
\hline
\end{tabular}

Note. $\mathrm{EC}=$ Effortful Control, $\mathrm{C}=$ Child, NA = Negative Affect, Surg = Surgency, DIBELS = Dynamic Indicators of Basic Early Learning Skills, T = Teacher, $\mathrm{CL}=$ Classroom, $\mathrm{CO}=$ Classroom Organization, $\mathrm{ES}=$ Emotional Support, $\mathrm{IS}=$ Instructional Support $* p<.05, * * p<.01$ 

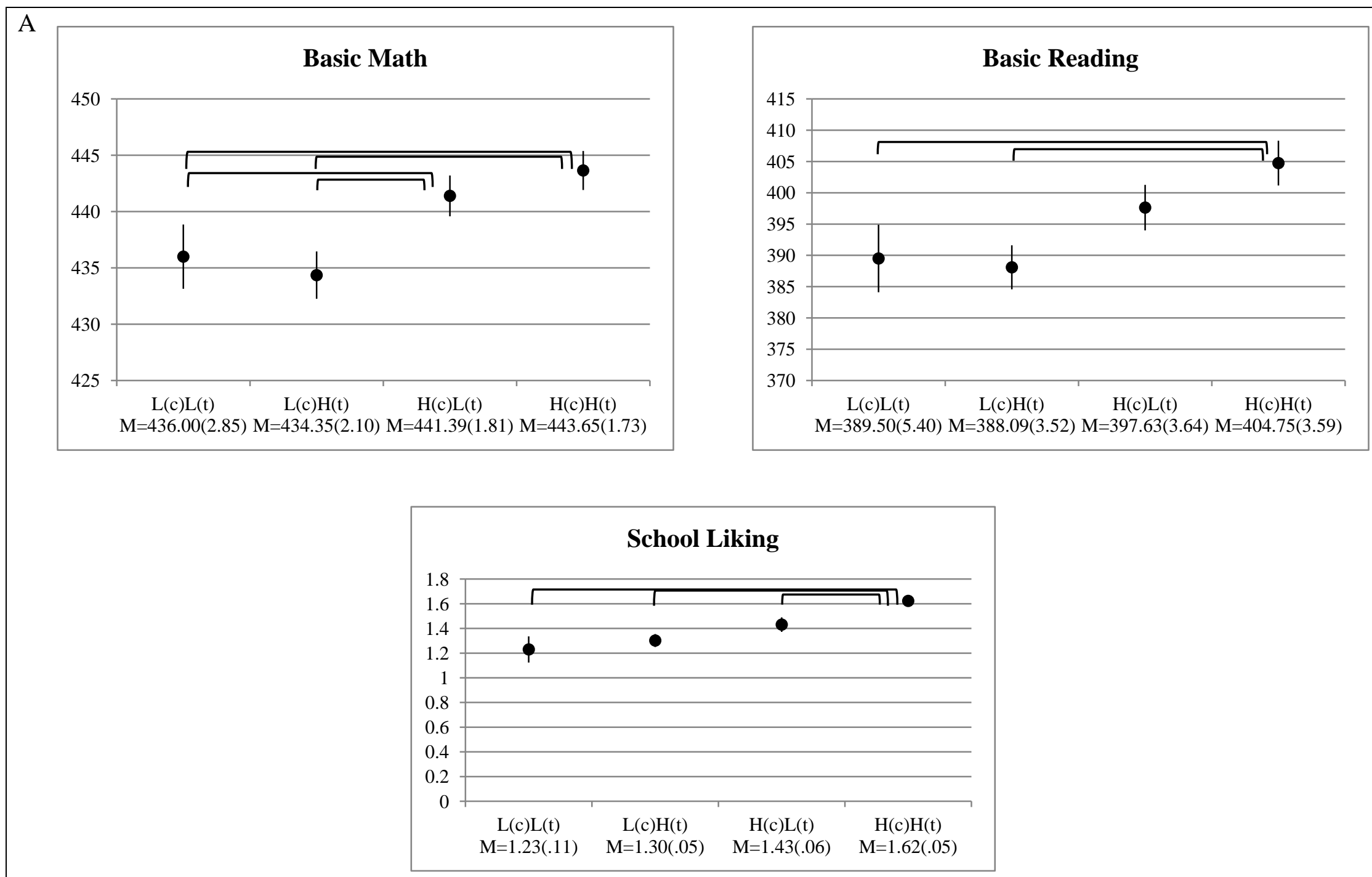

Figure 1. Plots of adjusted means (and standard errors) for student-teacher EC pairings on academic outcomes. Solid dots represent adjusted means, whereas extending lines represent 1 standard error below or above the adjusted mean. Brackets indicate significant mean differences between pairing groups. ${ }^{*} p<.05,{ }^{* *} p<.01$. 


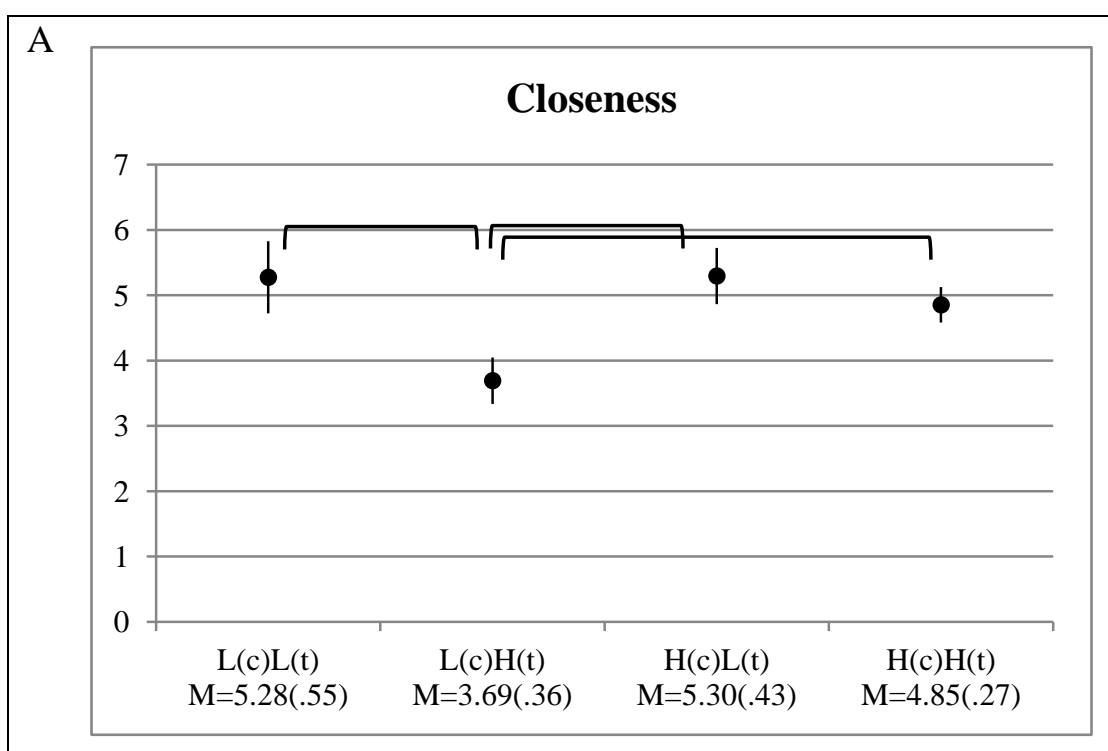

B

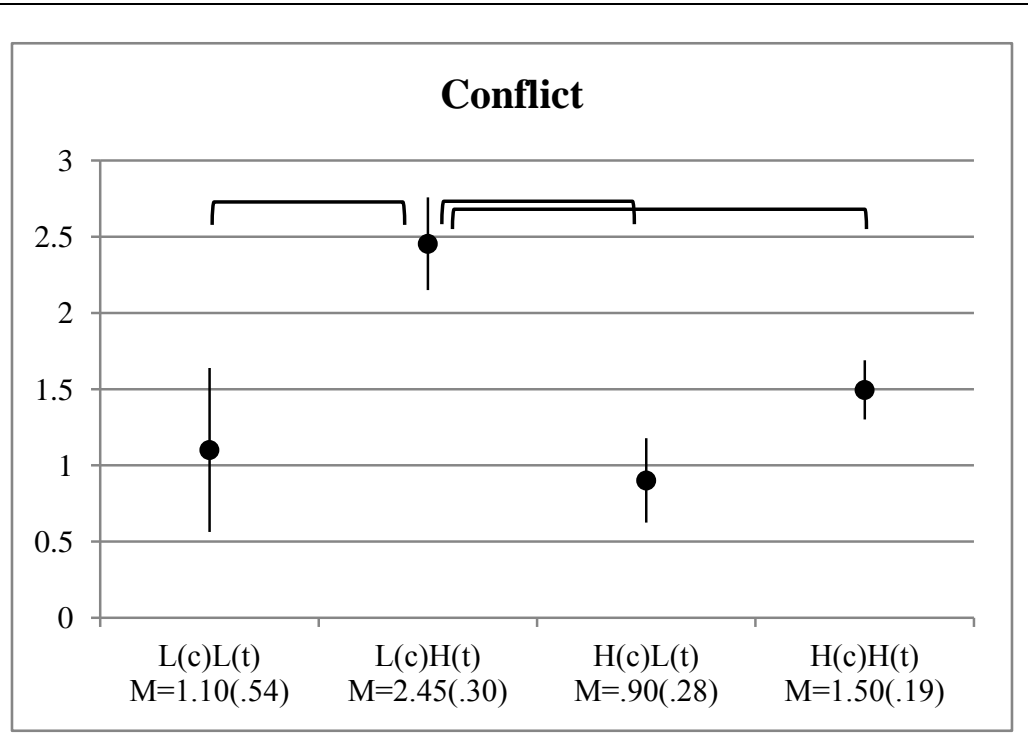

Figure 2. Plots of adjusted means (and standard errors) for student-teacher EC pairings on relational outcomes. Solid dots represent adjusted means, whereas extending lines represent 1 standard error below or above the adjusted mean. Brackets indicate significant mean differences between pairing groups. ${ }^{*} p<.05,{ }^{* * *} p<.01$. 